\title{
Repellent Effectiveness of Permot Leaf Ethanol Extract (Passiflora Foetida Linn.) against Aedes Aegypti Adult Mosquitoes
}

\author{
${ }^{1)}$ David Mohamad Qadafi, ${ }^{2}$ Poedji Hastutiek $(1,3)$ Lilik Maslachah, ${ }^{2)}$ Endang Suprihati, \\ ${ }^{4)}$ Muhammad Hambal
}

\author{
1)Student, Faculty of Veterinary Medicine, Universitas Airlangga, davidqadafi@gmail.com \\ ${ }^{2)}$ Division of Veterinary Parasitology, Faculty of Veterinary Medicine, Universitas Airlangga \\ ${ }^{3)}$ Division of Basic Veterinary Medicine, Faculty of Veterinary Medicine, Universitas Airlangga \\ ${ }^{4)}$ Department of Veterinary Parasitology, Faculty of Veterinary Medicine, Universitas Syiah Kuala \\ Corresponding author: poedjihastutiek@gmail.com
}

\begin{abstract}
Indonesia is one of the largest tropical countries in the world and various diseases can arise in the tropics which are caused by animals as vectors. An example of a vector that can carry diseases is a mosquito. Mosquitoes are insects that live side by side with humans buy act as vectors of disease. Mosquito Aedes aegypti is a type of mosquito that can carry the virus that causes Dengue Hemorrhagic Fever. This research was conducted to determine the effectiveness of Permot leaf ethanol extract (Passiflora foetida L.) as an alternative repellent against adult mosquitoes Aedes aegypti. This research was conducted from October to December 2020 and used Permot leaf ethanol extract consisting of 3 cream concentrations, namely $2.5 \%, 5 \%, 7.5 \%$, negative control using cream without permot leaf ethanol extract and positive control using mosquito cream. The data of this study were tested using one way ANOVA to find the effectiveness rate and comparations of the each Permot leaf repellent extract. This study proven that the permot leaf ethanol extract is effective as a repellent for Aedes aegypti mosquitoes.
\end{abstract}

Keywords : Permot Leaf, Passiflora foetida, Aedes aegypti, Repellent, ethanol ectract, mosquito.

\section{Introduction}

The Aedes aegypti mosquito is a type of mosquito that can carry the virus that causes Dengue Hemorrhagic Fever (DHF) (Ishartadiati, 2010). This mosquito usually bites in the morning until noon and reproduces by laying eggs in ditches, as well as in other places.

According to Taslimah (2014) mosquitoes are insects that live side by side with humans but act as disease vectors. Various diseases have been spread by no less than 2,500 species of mosquitoes (Herawati, 2010). Containers such as plastic waste, used bottles, used tires, cans and so on during the rainy season can become a breeding ground for mosquito larvae (Romandani, 2019).

Infectious diseases from the mosquito vector Ae. aegypti which has recently been endemic in Indonesia is dengue fever, the infectious disease which spread by the mosquito vector Ae. aegypti. Dengue Hemorrhagic Fever is an infectious disease caused by the dengue virus which can be transmitted through the bite of $A e$. aegypti, this disease is still a health problem in Indonesia. Effective prevention efforts are through controlling the mosquito in the environment.

Mosquitoes can also transmit diseases to animals not only to humans. The impact of disease on animals can cause losses for farmers due to decreased production of livestock. The Ministry of Health of the Republic of Indonesia (Depkes RI, 200o) states that mosquitoes are the most dangerous animals on earth in terms of the number of diseases that cause death, and the economic loss caused by mosquitoes.

Efforts to control Ae. aegypti as a vector of dengue disease which is widely applied today using a fumigation system and the use of insecticide Abate SG (Temephos 1\%). One of the practical vector control methods is to use mosquito repellent (Murrukmihadi and Dias, 2015). Repellent is a compound that works locally or at a certain distance, which has the ability to prevent mosquitoes from flying, landing or biting the surface of human skin 
(Djatmiko et al., 2010). Repelent that is often used by the public is in the form of cream. Synthetic repellents in the form of creams on the market still contain $\mathrm{N}, \mathrm{N}$-diethyl-m-toluamide (DEET) which can cause toxic effects. DEET is a synthetic repellent which has a broad spectrum and has been widely used in Indonesia.

The active substance DEET in this synthetic repellent product is corrosive so it can harm the injured skin. The use of natural repellents from plant materials can reduce the harmful effects of using DEET. This has prompted many researchers to conduct research on natural repellents derived from plants. Safe repellents are those that come from natural compounds (Murrukmihadi and Dias, 2015). Apart from being safe, repellent from plant materials has a distinctive aroma that is liked by humans but is not liked by mosquitoes (Aini et al., 2016). Permot plant (Passiflora foetida Linn.) is a medicinal plant that grows wild and is thought to have potential as a natural repellent (Susilowati, 2016). The leaf part of the permot plant is the part that contains the active compound as a repellent. Permot leaf ethanol extract contains alkaloids, terpenoids and phenols. Terpenoids contain isophytol and phytol which have properties as insecticides against Ae. aegypti (Hastutiek and Sunarso, 2013). Concentrations of $2.5 \%, 5 \%, 7.5 \%$ were determined based on Faiq's (2015) previous research, the amount of which had been adjusted. Based on the description above, it is necessary to conduct research to determine the effectiveness of the ethanol extract of permot leaves as a mosquito repellent for Ae. aegypti adult stage.

\section{Materials and Methods}

The sample used in this study waa $A e$. aegypti as many as 650 adult females from the Institute of Tropical Disease (ITD) Campus C UNAIR, Surabaya. Permot leaves were taken intentionally from the Keputih area in Surabaya. The leaves are sorted and then cleaned of adhering dirt by washing with clean water, drained and spread on newspapers so that the water evaporates, weighed as much as $7.5 \mathrm{~kg}$ dry weight, aerated for \pm one week by placing in a place protected from sunlight then mashed to form a smooth simplicia prepared for extraction. Extraction was carried out by maceration method using ethanol 96\% PA. Permot leaf simplicia used as much as 1000 grams was put in a maceration device and 96\% PA ethanol solvent was added until everything was submerged.
Then macerated for $3 \times 24$ hours at room temperature then filtered and the filtrate was accommodated. The filtrate was collected and evaporated at a temperature of $40^{\circ} \mathrm{C}$ using a rotary evaporator with decreasing pressure until a thick extract was obtained and then weighed. Evaporation was carried out to obtain a thick extract using an oven at $40^{\circ} \mathrm{C}$ to obtain a thick ethanolic extract of Permot leaves (Padmasari et al., 2013).

The basic cream preparation was carried out to obtain a suitable base cream formulation to be used as a repellent. The cream was made by mixing compounds (A) consisting of stearic acid, lanolin, and aquadest with compounds (B) such as glycerol, sodium hydroxide, triethanolamine, and aquadest in a ratio of $1: 1$ in a beaker over a bath at $80^{\circ} \mathrm{C}$ and stirred with a stirrer so that it is evenly distributed. The best formula is then used as the basis for making repellant creams. The percentage of materials used can be seen in Table 1.

Table 1. Base Cream Formulation

\begin{tabular}{lcc}
\hline Compounds & A & B \\
\hline Stearic acid & 16 & - \\
Lanolin & 0.5 & - \\
Sodium Hidroxide & - & 0.6 \\
Trietanolamine & 0.5 & 1.0 \\
Glycerol & - & 17 \\
Aquadest & ad 100\% & ad 100\% \\
\hline \multicolumn{2}{c}{ Source: Rahayu and Naimah, (2010) }
\end{tabular}

After obtaining the best formula for making the base cream, the formula was used for the negative control and treatment. To make repellant cream, the active compound of permot leaf ethanol extract is added to the base cream, with the variables of permot leaf ethanol extract being $2.5 \%, 5 \%$, and $7.5 \%\left(\mathrm{P}_{1}, \mathrm{P}_{2}, \mathrm{P}_{3}\right)$ and the mixing method can be seen in Table 2 .

Table 2. Repellant Cream Formulation

\begin{tabular}{ccc} 
Compound & Base Cream & Permot Extract \\
\hline 1 & 97.5 & 2.5 \\
2 & 95 & 5 \\
3 & 92.5 & 7.5 \\
K- & 100 & 0 \\
\hline
\end{tabular}

Permot leaf ethanol extract was weighed as needed. Permot leaf ethanol extract used is a concentration of $2.5 \%, 5 \%, 7.5 \%$. The determination of the concentration of the cream is based on previous research by Faiq (2015) whose concentration has been adjusted. The 
cream concentration of $2.5 \%$ was made by weighing the ethanol extract of Permot leaves as much as 2.5 grams then mixed with 97.5 grams of $\mathrm{o} / \mathrm{w}$ cream then ground with a mortar until homogeneous, while the cream concentration of $5 \%$ was carried out by weighing the ethanol extract of Permot leaves. as much as 5 grams and then mixed with 95 grams of cream and making cream with a concentration of $7.5 \%$ by weighing 7.5 grams of ethanol extract of Permot leaves then mixed with 92.5 grams of cream. After being homogeneous, it was put into a medicine pot and labeled for each treatment and ready to be used.

Three medicine containers are provided, each of which contains cream of ethanol extract of permot leaves with different concentrations. The experiment was carried out in the morning because the peak activity of mosquitoes occurred in the morning from 09.00-11.0o A.M. This research requires a trial volunteer. Volunteers used repellant cream on the right and left arms to then be tested directly on exposure to mosquitoes. Volunteers have certain conditions that must be met, among others; 1744 years old, healthy, not affected by malaria, filariasis, DHF, allergies, and have no injuries to the arms (Millati et al., 2018).

The first test procedure is the finger skin surface area to the arm skin surface (test object) smeared with 3 grams of repellent. The repellants were allowed to dry at room temperature. Both arms were put in a cage containing 25 female mosquitoes and then tested through the hole in the repellent test cage and counted with a stopwatch for 10 minutes referring to the research method of Fradin and Day (2002) which modified the time of observation of their perch. Then every 10 minutes thereafter until 5 replications observed the number of mosquitoes perched. The number of mosquitoes that landed on the arm was counted as soon as the hand entered the cage. The same thing was done for all treatments with 5 replications. Arms were put back in cages after 5 minutes pause after treatment. Each treatment was added with repellent, using a new cage, and different mosquitoes.

\section{Results and Discussion}

The results of observations made on the repellency of Ae. aegypti adults based on various treatments can be seen in Table 3

Research on the effectiveness of permot leaf ethanol extract ( $P$. foetida Linn.) against adult stage of Aedes aegypti mosquitoes showed that permot leaf ethanol extract had potential as a repellent. In this study, several different treatments were used, namely the provision of negative control, positive control and ethanol extract of permot leaves with different concentrations. The test was carried out by smearing the finger to the wrist using cream without ethanol extract of permot leaf for negative control, positive control using mosquito repellent lotion (Autan) ${ }^{\oplus}$ containing $\mathrm{N}, \mathrm{N}$-diethyl-m-toluamide (DEET) $13 \%$ and ethanol extract of Permot leaf. with different concentrations. This observation was carried out for 10 minutes. Before the test, the air temperature in the room when carrying out the test ranged from $26.3^{\circ} \mathrm{C}-28.8^{\circ} \mathrm{C}$ which is a proper temperature for the life, development and activity of mosquitoes in biting or searching for food (Rizki et al., 2015).

Table 3. Average and Standard Deviation of the Number of Mosquitoes Perched on Various Treatments

\begin{tabular}{cc}
\hline Treatment & Mean \pm SD \\
\hline $\mathrm{K}-$ & $24.00^{\mathrm{e}} \pm 0.70$ \\
$\mathrm{~K}+$ & $1.00^{\mathrm{a}} \pm 0.00$ \\
$\mathrm{P}_{1}$ & $17.00^{\mathrm{d}} \pm 0.70$ \\
$\mathrm{P}_{2}$ & $11.00^{\mathrm{c}} \pm 0.70$ \\
$\mathrm{P}_{3}$ & $3.00^{\mathrm{b}} \pm 0.70$ \\
\hline
\end{tabular}

Note: Different superscripts show significant differences $(\mathrm{P}<0.05)$.

Moreover, at a concentration of $7.5 \%$, an effective protection potency of $88 \%$ was obtained. Repellent testing using ethanol extract of permot leaves has a high average protection potency at the beginning of the test. The results of this study indicate that the effective concentration of ethanolic extract of permot leaves is at a concentration of $7.5 \%$ because the mosquito repel potency at this concentration is $84 \%$ at the beginning of use, namely at o-10 minutes. The effectiveness and duration of repellency of the repellent depends on the active compounds of the repellent formulation, application method, temperature, humidity, wind, and the attraction of mosquitoes to individuals (Suwasono and Blondine, 2009). This effectiveness can also be reduced due to evaporation, abrasion, absorption by skin and sweat, volunteer characteristics such as age, sex and biochemical attractiveness of mosquitoes in repellent test volunteers (Hidayah et al., 2018). 
The phytochemical results that have been carried out by Mena et al., (2016) show that the ethanolic extract of Permot leaves contains alkaloids, saponins, and flavonoids. This compound can attack nerve organs which can cause nerve weakness, such as breathing and death. Flavonoids can work as respiratory inhibitors. Inhibitors are substances that inhibit or reduce the rate of chemical reactions, and flavonoids can also interfere with the energy mechanism in the mitochondria by inhibiting the electron transport system (Basundari et al., 2018). Alkaloids have the ability to be good contact or stomach poisons because of their ability to penetrate insect cuticles (Hastutiek et al., 2017). Alkaloids are effective against a wide range of insects, particularly soft-bodied insects. In the nervous system this active compound acts on the ganglia of the central nervous system. Alkaloid compounds as contact and stomach poisons can kill insects slowly followed by stopped eating activities (Hastutiek and Sunarso, 2015).

Mosquitoes get fluids from food to maintain water balance. Mosquitoes also like a warm atmosphere because body temperature will affect the number of mosquitoes that perch. Mosquito behavior when searching for food is influenced by stimuli released by food sources (humans and animals), namely visual stimuli, warmth, humidity, smell and the presence or absence of carbon dioxide. Mosquitoes like a warm atmosphere and hands that emit a little moisture (Sanjaya et al., 2014). The repellent enters the respiratory system in the form of gas or fine particles which are carried to the mosquito's body tissues. The smell of permot leaf ethanol extract contains active compounds that mix with gases in the air which causes mosquitoes to not be attracted to this smell and will avoid it. The smell of the repellent is detected by chemical receptors found on the mosquito antenna, then the mosquito will convert it into impulses and forwarded by nerve axons to the central nervous system, which causes integration of the motor nerves to the brain so that mosquitoes avoid (Werdiningsih and Amalia, 2018). In addition, physiology, hunger, or satiety, sex and sexual development and eating habits at different developmental stages in each species affect the olfactory organs (Sanjaya et al., 2014).

The higher the concentration, the active compounds content of permot leaf ethanol extract, the higher the effectiveness of the repellent against Ae. aegypti. The active compounds of permot leaf ethanol extract as a repellent emits a pungent odor that will eventually keep mosquitoes away (Pettagading, 2018). This study proved that the ethanolic extract of permot leaf ( $P$. foetida Linn.) has active compounds that can be used as a mosquito repellent predominately for Ae. aegypti.

\section{Conclusion}

Based on the results of the research that has been done, it can be concluded that the ethanol extract of permot leaf ( $P$. foetida Linn.) has repellency against Ae. aegypti adult stage and ethanol extract with a concentration of $7.5 \%$ had a protective potency of $88 \%$ so that it could be said to be effective as a repellent against Ae. aegypti adult stage for 10 minutes according to the standards of the Ministry of Health of the Republic of Indonesia. Moreover, further research is needed such as using permot leaf extract ( $P$. foetida Linn.) with non-polar solvents such as n-hexane or semipolar solvents such as ethyl acetate. Furthermore, conducting further research on permot leaf extract ( $P$. foetida Linn.) with a higher concentration or more than $15 \%$ to reveal the effectiveness of the repellent against Ae. aegypti. In addition, it is also necessary to conduct further research on the effectiveness of the repellent ethanol extract of permot leaf $(P$. foetida Linn.) using the WHO standard with a protective potency above $90 \%$.

\section{References}

Aini, R., R. Widyastuti dan N.A. Nadhifa. 2016. Uji Efektifitas Formula Spray dari Minyak Atsiri Herba Kemangi (Ocium sanctum. L) sebagai Repellent Nyamuk Aedes aegypti. J. Ilmiah Manuntung. 2(2):189-197.

Basundari, S. A., Tarwotjo, U., dan E. Kusdiyantini. 2018. Pengaruh Kandungan Ekstrak Daun Zodia (Evodia suaveolens) terhadap Mortalitas Larva Nyamuk Aedes aegypti. Bioma. 20(1): 51-58.

Departemen Kesehatan RI. 20oo. Modul Epidemiologi Malaria. Ditjen P2M dan PLP. Jakarta. Hal 37.

Djatmiko M, Y. Anas, dan S.M. Handayani. 2011. Uji aktivitas repellent fraksi n-heksan ekstrak etanolik daun mimba (Azadirachta indicaa juss) terhadap nyamuk Aedes aegypti. E-Publikasi Fakultas Farmasi. 3(1):24-30. 
Faiq, M. 2015. Efektifitas repelen ekstrak daun Permot (Passiflora foetida L.) terhadap nyamuk culex fatigans dewasa [Skripsi]. Fakultas Kedokteran Hewan. Universitas Airlangga.

Fradin, M.S., and D.F. Day. 2002, Comparative Efficacy of Insect Repellents against Mosquito Bites, The New England Journal of Medicine, Chapel Hill Dermatology, 3(4): 1318.

Hastutiek P., dan A. Sunarso. 2013. Identifikasi Komponen Kimia Ekstrak daun Permot (Passiflora foetida Linn.) dengan TLC dan GC-MS sebagai Kandidat Bioinsektisida terhadap Nyamuk. Seminar Nasional Biologi/IPA dan Pembelajarannya di Universitas Negeri Malang 1-2 Nop 2014.

Hastutiek, P., dan A. Sunarso. 2015. Gambaran Histopatologi Saluran Pencernaan Larva Instrar IV Nyamuk Aedes aegypti setelah Perendaman dengan Senyawa Aktif Ekstrak Daun Permot (Passiflora foetida Linn.) dan Potensinya sebagai Bioinsektisida. Veterinaria Medika. 8(2): 137-144.

Hastutiek, P., Sunarso, A., and R.H. Prasetyo. 2017. Permot (Passiflora Foetida Linn.) Leaf Extracts as Bioinsecticide Against Aedes aegypti Larvae. The Southest Asian Journal of Tropical Medicine and Public Health. 48(6): 1169-1174.

Herawati, R. 2010. Ekstrak Daun Sirih (Piper betle L.) sebagai Insektisida Nabati untuk Membasmi Larva Nyamuk Aedes aegypti L. [Skripsi]. Fakultas Teknobiologi. Universitas Atma Jaya Yogyakarta. Yogyakarta.

Hidayah, N., Mustafa, H., Murni, dan I. Tolistiawaty. 2018. Efektivitas Repelen Losion Minyak Atsiri Kulit Jeruk Bali (Citrus maxima (Burm.) Merr.) terhadap Aedes aegypti. Balaba. 14(2):159-168.

Ishartadiati, K. 2010. Aedes aegypti sebagai Vektor Demam Berdarah Dengue. Universitas Wijaya Kusuma Surabaya. Surabaya. Hal 31.

Mena, P., Cirlini, M., Tassotti, M., A. Herrlinger, K., Dall Asta, C., and D. Del Rio. 2016. Phytochemical Profiling of Flavonoids, Phenolic Acids, Terpenoids, and Volatile Fraction of a Rosemary (Rosmarinus officinalis L.) Extract. PubMed. 21(11): 1-15.
Millati, F. F., Ferry, dan F. Sofian. 2018. Review Artikel: Kandungan Senyawa Minyak Atsiri pada Tanaman Pengusir Nyamuk. Jurnal Farmaka. 16(2):572-580.

Murrukmihadi, $\mathrm{M}$ and D.A. Fajarini. 2015. Repelen Activity Test of Essential Oil of Basil Leaves (Ocimum basilicum L.) (f. Citratum Back) against Aedes aegypti Lotion and Physical Characteristics Test of The Lotion. Traditional Medicine J. 20(2): 91-97.

Padmasari, P.D., K.W. Astuti, dan N.K. Warditiani. 2013. Skrining Fitokimia Ekstrak Etanol $70 \%$ Rimpang Bangle (Zingiber purpureum Roxb.). Fakultas Matematika dan Ilmu Pengetahuan Alam. Universitas Udayana. Denpasar. Hal 20.

Rahayu, S. P., dan S. Naimah. 2010. Pembuatan formulasi krim anti nyamuk dari fraksi minyak sereh. Jurnal Kimia dan Kemasan, 32(2): 53-61.

Rizki, D. A., Budiyono, dan R. Hestiningsih. 2015. Daya Tolak Repellent Bentuk Lotion dengan Ekstrak Daun Alpukat (Persea americana Mill) Terhadap Nyamuk Aedes aegypti Linn. Jurnal Kesehatan Masyarakat. 3(3): 702-711.

Romandoni, F. N. 2019. Hubungan Upaya Pencegahan terhadap Kejadian Penyakit DBD pada Masyarakat di Desa Gemaharjo Wilayah Kerja Puskesmas Gemaharjo Kabupaten Pacitan. [Skripsi] Stikes Bhakti Husada Mulia Madiun.

Sanjaya Y., Adisenjaya, Yusuf H., dan L. Wijayanti. 2014. Efektivitas Daya Tolak Ekstrak Geranium radula C. Terhadap Nyamuk Aedes aegypti (Linn.). Bionatura. 16(2): 62-67.

Susilowati, R.P. 2016. Uji Toksisitas Obat Nyamuk Bakar Herbal Berbahan Ekstrak Daun Permot (Passiflora foetida): Kajian Histopatologis Hati dan Ginjal Mencit. Prosiding SNPBS (Seminar Nasional Pendidikan Biologi dan Saintek) Ke-1 hal 492-497.

Suwasono, H., dan Ch. P, B. 2009. Uji Efikasi Repelen "X" terhadap Nyamuk Aedes aegypti, Culex quinquefasciatus dan Anopheles aconitus di Laboratorium. Jurnal Vektor 1(2): 101-108.

Taslimah. 2014. Uji Efikasi Ekstrak Biji Srikaya (Annona squamosal L.) sebagai 
Bioinsektisida dalam Upaya Integrated Vector Management terhadap Aedes aegypti [Skripsi]. Fakultas Kedokteran dan Ilmu Kesehatan. UIN Syarief Hidayatullah Jakarta.

Werdiningsih, I., dan R. Amelia. 2018. Lotion Ekstrak Daun Ekstrak Daun Zodia (Evodia sauveolens) sebagai Repellent Nyamuk Aedes sp. Jurnal Sains dan Seni. 1(1): 1-4. 